\title{
Implementation of Snowball Throwing Type of Cooperative Learning in Calculus Course
}

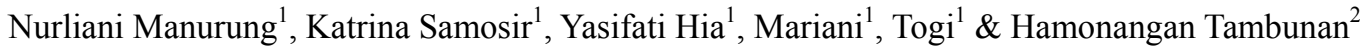 \\ ${ }^{1}$ Mathematics Education Study Program, Universitas Negeri Medan, Indonesia \\ ${ }^{2}$ Electrical Engineering Education Study Program, Universitas Negeri Medan, Indonesia \\ Correspondence: Hamonangan Tambunan, Jl. William Iskandar Psr. V Medan Estate, Medan, Sumatera Utara, \\ Indonesia.
}

Received: October 19, 2018

doi:10.5539/ies.v12n3p124
Accepted: December 1, 2018 Online Published: February 26, 2019

URL: https://doi.org/10.5539/ies.v12n3p124

\begin{abstract}
Our students experience difficulties in working on non-routine mathematical problems. They cannot see the general through special things or instead see things that are special through common things when dealing with mathematical concepts and examples. They cannot see the essential features of the way or recognize it when presented in various forms. We needed to improved their learning motivation and thinking creativity through the appropriate learning form. For that purpose, the action research was carried out by applying the snowball throwing type of cooperative learning in two cycles by involving as many as 70 participants in our calculus course. We implemented the teaching techniques for finding a diffractive solution in period 1 and the methods of solving differential equations in period 2. The learning implementation of period two was the improvisation of the cycle one' scenario by adding the learning resources, the Internet. The increase in learning motivation and thinking creativity had been able to meet the predetermined targets and concluded that the snowball throwing type of cooperative learning used in calculus lectures is useful.
\end{abstract}

Keywords: learning motivation, thinking creativity, snowball throwing, subject matter calculus

\section{Introduction}

The difficulties in learning mathematics often become obstacles in the learning process (Lithner, 2011), which are results in the deterioration of motivation and student learning outcomes. The motivation has been started playing a role in determining learning outcomes (Huang \& Wang, 2013; Davis, 1984). It is a psychological process that provides direction in achieving goals, which is driven by the desire to meet needs or make of the learning goals (Lin et al., 2007). The goal-oriented motivation category is the goal of the mastery approach, where personal competence describes their perception of self-improvement and self-set standards. It is defined as a direction to increase learning interest and a positive attitude towards learning (Pintrich \& Schunk, 2001). The learning outcomes are relatively stable changes as a result of the learning process, which consist of three types, namely knowledge in the form of factual information, interpretation of what observed when learning, and understanding. In another explanation, the learning outcomes include changes in respect, attitudes, and changes in emotions such as stopping the fear of exams, as well as rules about how to behave (Okland, 2012; Clark \& Nelson, 1993). These elements become the basis for evaluating the implementation of learning programs (Liu \& $\mathrm{Li}, 2015$ ), and determining the form of subsequent activities (Gates, 2017).

The students experience difficulties in working on mathematical problems, which appear when finding difficult non-routine issues. Students cannot know the general through special things or instead see that things are special through common things when learning mathematical concepts and examples. It indicates that students cannot see and recognize the essential features of the method in various forms presented (Roselainy et al., 2010). The inability to identify the intended functions is possibly related to the level of thinking creativity and the level of reasoning of the students because someone who is creative in thinking and has a high level of argument will appear when facing the problems (Lin et al., 2018; Tawarah, 2017). The person concerned not only views the issue from a partial angle but looks at the all possible aspects related to the problem (Pringle \& Sowden, 2017). The frequency of adequate training can generate creative thinking. It faced with various issues and practices in feelings that are not depressed as often as possible when the person is very likely to be creative in thinking when solving problems (Kao, 2014; Montag-Smit \& Maertz, 2017; Wechsler et al., 2018). 
The above description was the basis of the importance to improve the calculus learning in our institution-State University of Medan because the student learning achievement is not in line with expectations in the last two years. There are only $11.9 \%$ of 70 college participants on average can solve the problems correctly. It needed more active learning methods for teaching students. The diverse learning models used included direct learning, tutorial forms, and learning assignments and exercises. It is possible that all of them are not by the characteristics of student learning. The survey results involving 26 participants showed tended to experienced tension when attending lectures (57\%). There were 39\% who said they were less motivated because they felt under pressure. Based on the results of interviews with ten college participants about the difficulties experienced in the lecture, the students need to collaborate with other participants in learning, especially when solving mathematical problems faced. The learning difficulties can be overcome by (1) Making the higher education more flexible and adaptable as a new social task; (2) Tracing the characteristics and causes of learning difficulties through the research (Moreno \& Rutledge, 2017); (3) Making the better connection between research and development (Mostofo \& Zambo, 2015). The instructors played a role as a researcher (Huillet, Adler, \& Berger, 2011; Rahman, Yusof, \& Baharun, 2012). The teacher is expected to be able to design learning with conceptual models and strategies that can build creative thinking (Black, Freeman, \& Stumpo, 2015; Konstantinou-Katzi et al., 2013; Towers et al., 2013).

A creative thinking can emerge from the various processes for producing the solutions, namely the one was through the unique procedure, which is a mixture of automatic, unconscious (type 1), the two was the routine processes of the mix of the associative and deliberative, and the conscious and analytic (model 2). In the field of insight and creativity, the type 1 processes are seen to have a positive role, which leads to new solutions that may be difficult, or impossible to achieve by the correct kind 2 of analytical control processes (Gilhooly, Ball, \& Macchi, 2014). The students' thinking creativity formed seen in the intention, novelty, and value shown. It is a defining characteristic, coupled with other attributes such as elegance, acceptance of ethics, and wisdom. Products that are well-made, aesthetic, simple, concise, and deliberately economical are showing taste. Knowledge refers to consideration of how, or even if individual products used, and of course, the creative products must be ethically acceptable in production and goals (Newton \& Newton, 2010). The collaborative condition which created through the learning that accommodates shared learning situations for students is called cooperative learning ( $\mathrm{Yi} \& \mathrm{LuXi}$, 2012). It is one of the many types of learning models available, which have the characteristics of overcoming the difficulties mentioned above (Ahmadi, 2000). Cooperative learning, therefore, refers to students who work and learn together in groups to perform tasks and achieve the expected goals. The teacher needs to prepare, to plan, and guidance because it is not just as a collaborative process (Speer, Smith, \& Horvath, 2010).

There are several types of cooperative characteristics; one of them is the snowball throwing type, which characterized learning with a cheerful situation. The learning motivation can be increased through this learning because avoided by the feeling depressed (Supu, 2018; Wang \& Hsieh, 2017). By the conditions like this are possible to increase the creative thinking because of the motivation is the basis for building oneself to be creative and the level of reasoning increased. This paper is explained the cooperative teaching of snowball throwing type implementation in teaching calculus, which based on the teaching and learning theory. The students' cognitive processes categorized the different levels in analyzing and designing learning by using the revised Bloom Taxonomy, namely evaluating dan creating (Anderson \& Krathwohl, 2001). Some research findings have supported that the thinking at a higher level only through such a process which allows one to learn beyond the information provided. The contents of the lesson must be considered and more often contemplated to obtain a more detailed and integrated knowledge structure and applied in transferring the new, different tasks from those presented in the lesson (Bransford, Brown, \& Cocking, 2000). The information processing at a higher level (evaluating and testing the level of understanding of information) is called the creative thinking, which the student's general ability had been determined, measured, and introduced (Padget, 2013). Another understanding of creative thinking is the student learning strategy in terms of how students apply and report prior knowledge to new situations in solving problems, making decisions, and making critical evaluations. This way supported learning achievement and learning independence (Neber, He, Liu, \& Schofield, 2008). It reflected the level of creative thinking in the reflection process, which represents a higher level of taxonomy, and the process of evaluation and criticism of the validity of the content of the lesson (Kember \& Leung, 2005). Critical reflection is a meaningful predictor of mathematical achievement, measured through a report scales self (Phan, 2005).

Creativity can be explained based on products, processes, or even the environment. The results or innovations are from the product side. The different thinking or a series of problem-solving leading to productive completion is the process-based creativity. While related to the visible environment of work, social contextual. In general, this conception defined and measured to produce the new job, which promoted through additional programs used in the classroom or by extracurricular programs (Hunsaker, 2005). Changes in environmental conditions towards 
student-oriented instruction, which are intended for the development of creative abilities (Lockette, 2012). One of the results of research in China shows that outside of classroom-based instruction. All students attending school need further extracurricular activities in the chosen domain. The opportunity and experience to practice and develop creative abilities are more than in regular classes. The opportunities expanded explicitly given to high-ability and high-achieving students. However, the evidence is missing if students apply critical and creative thinking in their extracurricular environment more intensively than the subject of learning determined in their class (Zhao \& Zhao, 2012). The creativity is general ability through most approaches. However, only a few of them explained it through a higher learning process or a strategy used by students as an instrument or tool in generating knowledge in subjects taught in school. In a revised taxonomy, "making" represents the upper-level cognitive process. As a macro level process, creation is related to generating knowledge structures by elaborating and integrating information from various sources. The requires sub-process thinking such as combining, modifying, and even creating important means to transcend the information presented by the teacher (Anderson \& Krathwohl, 2001).

The students are accustomed to thinking creatively about the subject matter and formed the high abilities - high ability in particular domains in mathematics lessons (Ziegler, 2009). The high abilities will complete mathematical content and curricular tasks in ways that are varied, flexible and creative (Wolfe, 1986). Also, various elaborations can determine higher achievement (Hwang, Chen, Dung, \& Yang, 2007). Interest in cooperative learning has developed when schools have realized their academic and social usefulness in students, which obtained when working together and helping each other. The academic benefits gained include improved performance in reading vocabulary and developing understanding, written expression, and understanding of mathematics, and conceptual development in science (Gillies in Gillies \& Ashman, 2003). It expressed as the term learning cooperation because it provides opportunities for students to work with other students in structured assignments. The study groups are formed to achieve the goals that are predetermined.

The controversy about why and how cooperative learning methods affect achievement, and under what conditions cooperative learning has these effects still exists even though some agree with the positive effects they have. The various groups of researchers, who examine the effects of cooperative learning on achievement, begin with the different numbers and conclude by explaining the effects of achieving cooperative learning in entirely different theoretical terms. The motivation, social cohesion, cognitive development, and cognitive elaboration are the four main theoretical perspectives on the effects of cooperative learning. A motivational perspective assumes that task motivation is the most influential part of the learning process. It emphasized that personal interests motivated by individuals drive other processes such as planning and assistance. Motivated-oriented focuses more on rewards or the structure of goals in which students operate (Slavin, 2009). The methods derived from this perspective emphasize the use of group goals and individual accountability, which means that group success, depends on individual learning from all group members. In contrast, social cohesion perspectives (also called social interdependence theories) show that the effects of cooperative learning depend heavily on group cohesiveness. In this view, students help each other to learn because they care about the group and its members and benefit from group membership (Johnson \& Johnson, 1998), which focused on the interaction between groups of students in achieving a better learning goal.

Cooperative learning is a complement to other views, not contradictory. Motivation theory will not refute cognitive theories that are not needed but emphasized that motivation encourages cognitive processes, which in turn produce learning (Slavin, 1995). Students are not likely to be involved in the long run (Webb, 2008) and what matters more is to benefit from collaborative activities in addition to learning from their teammates. Social cohesion theorists argue that the utility of extrinsic incentives must lie in their contribution to cohesive groups, caring, and prosocial norms among group members, which in turn can affect cognitive processes - in practice, beginning with a focus on group goals or incentives based on individual learning from all group members. The initial assumption that motivation to learn is to encourage and help others to learn in activating cooperative behavior. It includes motivation and motivation for the task to interact in groups. In this model, motivation to succeed leads to direct learning, and also encourages behaviors and attitudes that lead to group cohesion, which in turn facilitates the types of group interactions that enhance learning and academic achievement. The relationship contained becomes reciprocal because task motivation leads to the development of group cohesion, which can strengthen and enhance task motivation. In the same way, cognitive processes can be intrinsically beneficial and lead to increased task motivation and group cohesion.

Some of the research results are sufficient evidence to support the use of cooperative learning in improving learning outcomes. The purpose of groups or awards for groups improves the achievement of cooperative learning outcomes, if and only if group rewards based on individual learning from all group members. The team can 
succeed is by making sure all team members have learned. Team member activities focus on explaining concepts to each other, helping one exercise, and encouraging each other to achieve it (Slavin, 2009, 2015). Group goals and individual accountability are considered alternatives. In some forms of cooperative learning, students work together to complete one worksheet or solve a problem. In such a method, there is little reason for students who are better able to take the time to explain what happened to their less fortunate friends or to ask their opinions. When the group's task is to do something, the participation of underprivileged students seen as interference rather than help, it may be more comfortable in this situation for students to give answers than to explain concepts or skills to each other. More aggressive students can dominate the group, and others may avoid participating, allowing others to work (and learn). When group assignments are to ensure that each group member learns something, it is each group member' interest to spend time explaining concepts to their group friends, and asking group friends for explanations and helping in understanding learning topics. In cooperative groups, students who get the most out of cooperative work are those who give and receive the explanations described (Webb, 2008). The answers gave and received without explanation become the result is low. Group goals and individual accountability are motivating students to give detailed explanations and take serious learning from each other, rather than just giving answers.

There are two main categories of cooperative learning, namely (1) Structured Team Learning, which involves team rewards based on their members' learning progress, and individual accountability, which means that team success depends on individual learning, not group products; (2) Informal Group Learning Methods, which are methods that focus more on social dynamics, projects, and discussion rather than mastering well-defined content (Gillies, 2016). One type of much cooperative learning developed is the snowball throwing type which is also characterized by the learning groups in special characteristics. It is like a game in throwing a ball for provoking creativity by making the questions when testing the absorption capacity of the material delivered by the group leader. Because in the form of games, the students are conditioned in a relaxed state but still controlled not noisy, chaotic or troublesome. It does through several steps, namely by delivering the material presented through the group leaders who are formed and forwarded to their respective groups. Moreover, then, one of the worksheets was given to each participant to write down any questions related to the material which was explained by the group leader. Moreover, then the paper is squeezed to be the round shape (made like a ball) and thrown by one student to another student for 5 minutes approximately. The students who get the paper containing the questions get the opportunity to answer the questions written on the ball-shaped paper alternately, which continues with the evaluation. It is the necessary process because the communicative characteristics were learning, namely a two-way learning system (teachers and students play an active role), and fun. It trains students' readiness, gives each other knowledge. The advantage of this learning approach is the communicative learning atmosphere.

\section{Method}

The idea of this study was to improve our students' learning outcomes, which are the participants of the Mathematics Course at the State University of Medan. Therefore we do the action research, which adopted the model of Elliot (1991) in two cycles through the stage of plan, implementation, evaluation and, reflection. In cycle 1 , the planning stage based on the surveys and interviews conducted which obtained the students experienced difficulties in learning (71\%), especially solving problems in the application of mathematical concepts. Based on this, It was decided to overcome by using the snowball throwing type of cooperative learning model, which has unique characteristics, namely the mild learning conditions, so their anxious feelings avoided by implementing these model. The learning motivation can be triggered and supported the formation of creative thinking and reasoning level.

In the line of that, the learning scenarios were developed which contain the learning procedure, include (1) conveying to students that the material is about techniques for finding a diffractive solution. The students' competencies expected formed, which indicated by recognizing the types of techniques used in solving differential equations; (2) forming the students' study group by four students of each group, and appointing one person of them to become the group leader. (3) Give each groups' chairman the topics, and to provide an explanation of the material; (4) instructing the heads of each group to return to their respective groups; (5) each group leader presents the lecturer's explanation received from the lecturer to their group members; (6) Giving each of student one sheet of work paper, and ask to write down one question regarding the material that has been explained by the group leader; (7) The paper containing the question is made like a ball by everyone thrown from one student to another for \pm 5 minutes; (8) After each student gets one ball / one question, then the opportunity is given to students to answer the questions written in the ball-shaped paper alternately.

In the next stage this scenario was implemented, and at the same time observed the students' learning motivation by using the observation sheet. At the evaluation stage, the creative thinking we tested at the end of the learning. It turned out that the specified target had reached, so it was decided to plan scenario two. Based on the refection of 
cycle 1, It was designed the learning scenarios of cycle 2, by adding the learning resource addition. The Internet use as an aid to learning resources in overcoming the problems that arose in cycle one and used when resolving the problems faced in a ball-shaped paper.

\subsection{Data Collection and Collection Tools}

The learning motivation data on the initial state was collected by the learning motivation questionnaires which consist of 54 items in 5 options by the reliability coefficient of 0.69 . The possible scores get through this instrument are 54 up to 220 . The data on cycle 1 and cycle two were collected by the observation sheet, which done at the same time of implementing the learning scenario. We recorded (1) the level of cooperation activities with groups; (2) the activity level in opinion; (3) the activity level in helping group members; (4) the activity level in working on the task; (5) the activity level in tracking the sources needed by the group; (6) the activity level in making the group work reports; (7) the job neatness; (8) the courage in displaying the work results; (9) the readiness to lead groups; (10) the responsibility for group work. The scoring is between 0 and 100.

We collected the participants' creative thinking level data on the initial state by using Treffinger's creative thinking tests by scoring the range of 0 to 100 . While measured through the accuracy level in answering the issues faced by the differential lecture material in the cycle 1 and cycle 2, they were, including the mathematical problem modeling, completion procedures, and accuracy of the results obtained, also by scoring between 0 and 100 .

\subsection{Participants and Research Targets}

We involved as many as 70 students of two class as the participants in this study and targeted at least $55 \%$ of the participants had learning motivation and creative thinking in the high category. The related categories were determined based on the ideal mean score (M) and standard deviation (Sd). The categories are (1) the very low category, $\mathrm{M}-3 \mathrm{Sd}<\mathrm{Score} \leq \mathrm{M}-2 \mathrm{Sd}$; (2) the low category, $\mathrm{M}-2 \mathrm{Sd}<\mathrm{Score} \leq \mathrm{M}-1 \mathrm{Sd}$; (3) the medium category, $\mathrm{M}-1 \mathrm{Sd}<$ Score $\leq \mathrm{M}+1 \mathrm{Sd}$; (4) the high category, $\mathrm{M}+1 \mathrm{Sd}<\mathrm{Score} \leq \mathrm{M}+2 \mathrm{Sd}$; and (4) the very high category, $\mathrm{M}$ $+2 \mathrm{Sd}<$ Score $\leq \mathrm{M}+3 \mathrm{Sd}$.

\section{Results}

\subsection{Learning Motivation}

The existence of the participants learning motivation appears to increase from the initial state to cycle 1 and cycle 2 . In the initial stages was at the low category $(108<129.93<135)$, the cycle 1 was at the sufficient category (40 $<41.43 \leq 60)$, and the cycle 2 was at the high category $(60<75.79 \leq 80)$. The learning motivation data analysis of the initial state, cycle 1, and cycle 2 looked like in Table 1.

Table 1. Learning motivation description

\begin{tabular}{cccccccc}
\hline Condition & $\mathrm{N}$ & Minimum & Maximum & Mean & Std. Error & Std. Deviation & Variance \\
\hline Early & 70 & 100 & 155 & 129.93 & 1.658 & 13.870 & 192.386 \\
Cycle 1 & 70 & 15 & 65 & 41.43 & 1.724 & 14.425 & 208.075 \\
Cycle 2 & 70 & 60 & 95 & 75.79 & 1.000 & 8.368 & 70.026 \\
\hline
\end{tabular}

The scores distribution of the three learning motivation conditions appears in Table 2. The motivation to learn of the participants is to increase from the initial state to be the end condition of cycle 1 and cycle 2 . In the early, there were $7.1 \%$ of participants having learning motivation in the deficient category, $60 \%$ in the low category, and $32.9 \%$ in the medium category. After cycle 1 , there were $11.4 \%$ of students still at the very low category ( 0 $\leqslant$ Score $\leqslant 20) ; 34.3 \%$ are at the low rank $(20<$ Score $\leqslant 40) ; 65.7 \%$ are at the sufficient category $(60<$ Score $\leqslant 80)$. The situation is increasing in cycle 2 . There were $4.3 \%$ at the moderate category $(40<$ Score $\leqslant$ $60)$, as many as $75.7 \%$ were in the high category $(60<$ Score $\leqslant 80)$, and as many as $20 \%$ were in the very high category $(80<$ Score $\leqslant 100)$.

Table 2. Learning motivation scores distribution

\begin{tabular}{ccccccccc}
\hline & Early & \multicolumn{9}{c}{ Cycle 1 } & \multicolumn{2}{c}{ Cycle 2 } \\
\hline Score & Frequency & $\begin{array}{c}\text { Cumulative } \\
\text { Percent }\end{array}$ & Score & Frequency & $\begin{array}{c}\text { Cumulative } \\
\text { Percent }\end{array}$ & Score & $\begin{array}{c}\text { Frequency } \\
\text { Cumulative } \\
\text { Percent }\end{array}$ \\
\hline 100 & 1 & 1.4 & 15 & 2 & 2.9 & 60 & 3 & 4.3 \\
105 & 4 & 7.1 & 20 & 6 & 11.4 & 65 & 10 & 18.6 \\
110 & 5 & 14.3 & 25 & 8 & 22.9 & 70 & 12 & 35.7 \\
\hline
\end{tabular}




\begin{tabular}{|c|c|c|c|c|c|c|c|c|}
\hline 115 & 5 & 21.4 & 30 & 7 & 32.9 & 75 & 15 & 57.1 \\
\hline 125 & 7 & 40.0 & 40 & 1 & 45.7 & 85 & 8 & 91.4 \\
\hline 135 & 10 & 67.1 & 50 & 10 & 72.9 & 95 & 2 & 100.0 \\
\hline 140 & 9 & 80.0 & 55 & 9 & 85.7 & - & - & - \\
\hline 150 & 5 & 97.1 & 65 & 4 & 100.0 & - & - & - \\
\hline 155 & 2 & 100.0 & - & - & - & - & - & - \\
\hline Total & 70 & & & 70 & & & 70 & \\
\hline
\end{tabular}

\subsection{Creative Thinking}

Based on predetermined comparative criteria, on average, the state of the creative thinking level of the participants was in a low category $(20<35.93 \leqslant 40)$. In cycle 1 , the students thinking creativity in solving the problems faced on an average level is still insufficient rank $(40<51.29 \leqslant 60)$. Moreover, in cycle 2 , the level of creative thinking and reasoning of participants on average is in the very high category $(80<$ Score $\leqslant 100)$. It seems in Table 3.

Table 3. Creative thinking description

\begin{tabular}{cccccccc}
\hline Condition & $\mathrm{N}$ & Minimum & Maximum & Mean & Std. Error & Std. Deviation & Variance \\
\hline Early & 70 & 20 & 50 & 35.93 & 1.069 & 8.940 & 79.922 \\
Cycle 1 & 70 & 40 & 65 & 51.29 & .855 & 7.157 & 51.222 \\
Cycle 2 & 70 & 60 & 95 & 81.00 & 1.108 & 9.270 & 85.942 \\
\hline
\end{tabular}

The creative thinking scores distribution of the three conditions appears in Table 4. It seems there is an increase from the early to cycle 1 and cycle 2 . In the early, there were $8.6 \%$ of participants having creative thinking in the deficient category $(0 \leqslant$ Score $\leqslant 20), 62.8 \%$ in the low category $(20<$ Score $\leqslant 40)$, and $28.6 \%$ in the sufficient category. After Cycle 1, there were $10 \%$ of students still in the low category $(20 \leqslant$ Score $\leqslant 40)$; $81.4 \%$ are in the sufficient rank $(40<$ Score $\leqslant 60) ; 8.6 \%$ are in the high category $(60<$ Score $\leqslant 80)$. The situation is increasing in cycle 2 . There were $4.3 \%$ at the moderate category $(40<$ Score $\leqslant 60)$, as many as $47.1 \%$ were in the high category $(60<$ Score $\leqslant 80)$, and as many as $48.6 \%$ were in the very high category $(80<$ Score $\leqslant 100)$.

Table 4. Creative thinking distribution

\begin{tabular}{|c|c|c|c|c|c|c|c|c|}
\hline \multicolumn{3}{|c|}{ Early } & \multicolumn{3}{|c|}{ Cycle 1} & \multicolumn{3}{|c|}{ Cycle 2} \\
\hline Score & Frequency & $\begin{array}{c}\text { Cumulative } \\
\text { Percent }\end{array}$ & Score & Frequency & $\begin{array}{c}\text { Cumulative } \\
\text { Percent }\end{array}$ & Score & Frequency & $\begin{array}{c}\text { Cumulative } \\
\text { Percent }\end{array}$ \\
\hline 20 & 6 & 8.6 & 40 & 7 & 10.0 & 60 & 3 & 4.3 \\
\hline 25 & 9 & 21.4 & 45 & 17 & 34.3 & 65 & 5 & 11.4 \\
\hline 30 & 10 & 35.7 & 50 & 17 & 58.6 & 70 & 5 & 18.6 \\
\hline 35 & 12 & 52.9 & 55 & 15 & 80.0 & 75 & 7 & 28.6 \\
\hline 40 & 13 & 71.4 & 60 & 8 & 91.4 & 80 & 16 & 51.4 \\
\hline 45 & 14 & 91.4 & 65 & 6 & 100.0 & 85 & 17 & 75.7 \\
\hline 50 & 6 & 100.0 & - & - & - & 90 & 10 & 90.0 \\
\hline - & - & - & - & - & - & 95 & 7 & 100.0 \\
\hline Total & 70 & & & 70 & & & 70 & \\
\hline
\end{tabular}

Graphically, the learning motivation and creative thinking increase in the two cycles of the snowball throwing implementation shown in Figure 1. 


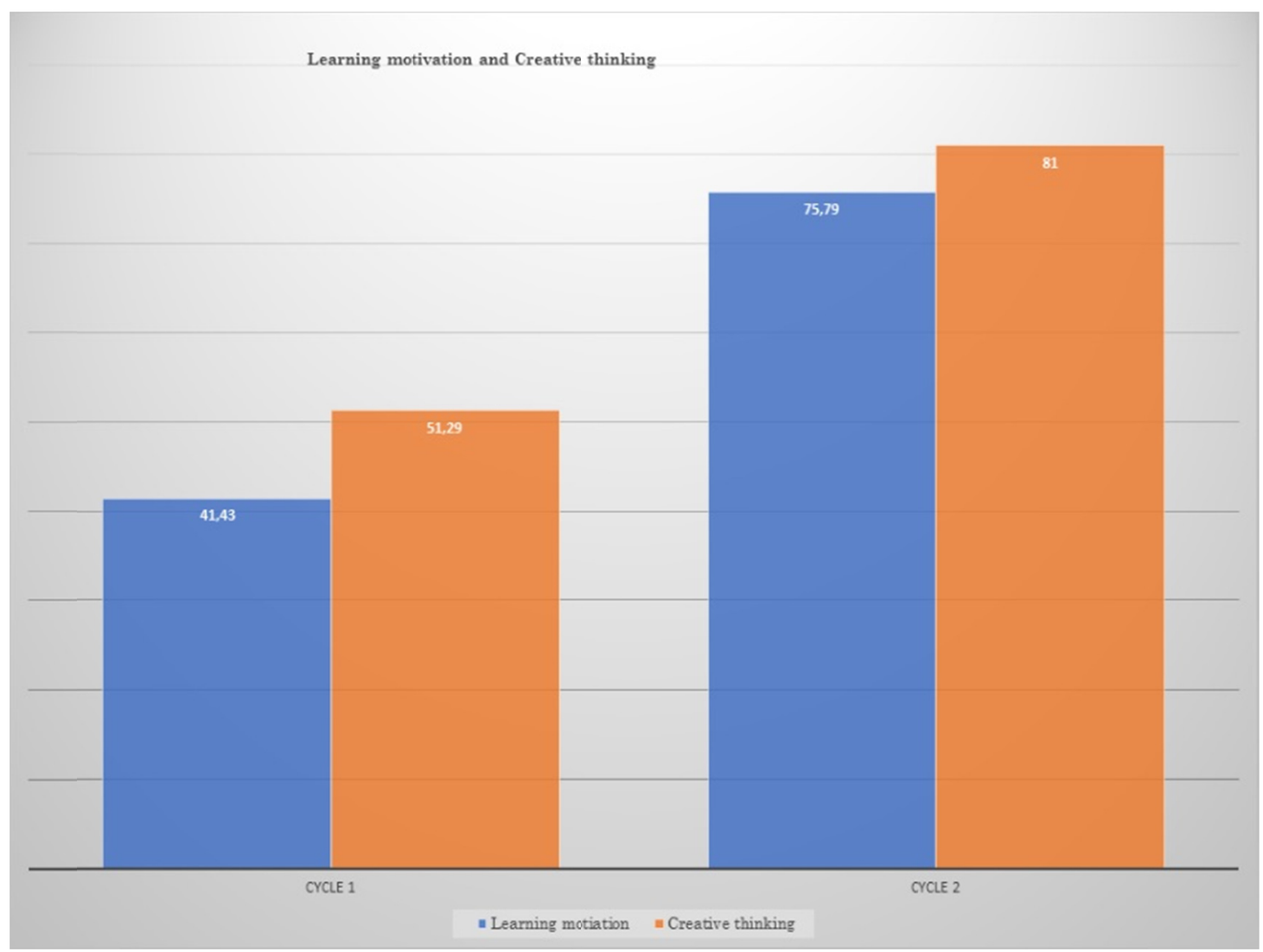

Figure 1. Learning motivation and creative thinking in the calculus course

\section{Discussion and Conclusion}

The results of this study as intended are to improve the learning motivation and the critical and creative thinking in the classroom. It appears that it is not only possible to use a higher level process in context, but also provides evidence that it can function as an effective instrument to produce and obtain specific knowledge about the curriculum needed. The results of all the cycle clearly show that people who are above average in the exam apply more intensive critical and creative thinking as instruments or strategies for learning than low-achieving students. Likewise, those who are capable of creative thinking seem to be at different levels in both situations.

By applying snowball throwing learning in cycle 1, it created students' learning enthusiasm, and there is a feeling of pleasure in learning situations that at first glance are in the form of entertainment. It seem from the increase in the number of students active during the learning activities. However, at this stage, what is the initial target is not yet achieved. Through reflection, it turns out that students need help with learning resources that can help them when solving problems they get. In the second cycle of this study, students were facilitated by providing sites that provided information related to the problems they were working. This situation is quite a positive impact on learning motivation, and so is the creative thinking of them also increases.

It concludes that especially in low achieving students do not use their potential for learning purposes in calculus classes. It is a way to intensify the use of critical and creative thinking by students. Teachers must assume that students even with relatively lower achievements in mathematics can think critically and creatively about the information and tasks are given in their classrooms. As a result of a study that found that even more than $80 \%$ of teachers believe that only high achieving students can think of a higher level than Bloom's taxonomy, and therefore it is justifiable to treat students not to be condemned (Zohar, Degani, \& Vaaknin, 2001). In line with the findings of Zohar \& Dori (2003) which states that high-level thinking processes support science classes. Students with low achievement improve their learning performance as a result of interventions related to the short process. Support from the lecturers' experience to evaluate and describe the content provided in the classroom contributes more positively. The study results indicate that this is a way to increase the level of critical and creative thinking of people who are below average in calculus subjects. Lecturers can pursue this approach in their teaching without burdening them cognitively. It because there is no need to design learning tasks that are entirely new as 
suggested by Krulik and Rudnick (1999), or applying new radical teaching methods as suggested by reform education as far as this has not been effective in increasing the level of creative thinking (Von Lockette, 2012), if it makes students depressed.

The second promising way to strengthen critical and creative thinking is the motivation to learn student calculus. In the 3P model (Biggs, 1992), motivation is an important characteristic, and repeatedly confirms the characteristics of a student-specific perspective that mediates such a high-level learning process (Lau, Liem, \& Nie, 2008). The results for learning motivation related to calculus, the value of the task supports them with achievements above average. However, promoting mediators from this kind of process in class may be more challenging for Lecturers than pursuing the first method. One reason is that it does not directly focus on the higher level learning process but on increasing the motivational prerequisites for the process. The student learning independence seems to be one of the factors that teachers need to build that allows them to choose a promising approach in increasing self-efficacy for learning calculus from people who are below average. The teacher determines the formulation of individual learning goals by those with low achievement through reducing comparisons with students who have higher achievement and intensifying student perseverance in thinking about the problem of calculus by the teacher through a verbal persuasion approach that is easily implemented (Korn, 2010). Based on the results obtained it concluded that the type of snowball throwing cooperative learning provides an opportunity to increase motivation to learn and think creatively from students.

\section{Acknowledgments}

We want to thank the State University of Medan, who funded this research.

\section{References}

Ahmadi, M. H. (2000). The impact of cooperative learning in teaching mathematics. Primus, 10(3), 225-240. https://doi.org/10.1080/10511970008965961

Anderson, L., \& Krathwohl, D. A. (2001). Taxonomy for Learning, Teaching and Assessing: A Revision of Bloom's Taxonomy of Educational Objectives. New York: Longman.

Biggs, J. B. (1992). Why and how do Hong Kong students learn? Hong Kong: The University of Hong Kong.

Black, C., Freeman, C., \& Stumpo, G. (2015). Conceptual model and strategies for creative thinking in apparel design. International Journal of Fashion Design. Technology and Education, 8(2), 131-138. https://doi.org/10.1080/17543266.2015.1018958

Bransford, J. D., Brown, A. L., \& Cocking, R. R. (Eds). (2000). How People Learn: Brain, Mind, Experience and School. Washington D.C.: National Academy Press

Clark, H. C., \& Nelson, M. N. (1993). Improving Mathematics Evaluation through Cooperative Learning Strategies. Middle School Journal, 24(3), 15-18. https://doi.org/10.1080/00940771.1993.11495889

Davis, W. J. (1984). Motivation and learning: Neurophysiological mechanisms in a "model" system. Learning and Motivation, 15(4), 377-393. https://doi.org/10.1016/0023-9690(84)90004-3

Elliot J. (1991). Action Research for Educational Change. Celtic Court: Open University Press

Gates, E. F. (2017). Learning from seasoned evaluators: Implications of systems approaches for evaluation practice. Evaluation, 23(2), 152-171. https://doi.org/10.1177/1356389017697613

Gilhooly, K. J., Ball, L. J., \& Macchi, L. (2014). Insight and creative thinking processes: Routineandspecial. Thinking \& Reasoning, 21(1), 1-4. https://doi.org/10.1080/13546783.2014.966758

Gillies, R. (2016). Cooperative Learning: Review of Research and Practice. Australian Journal of Teacher Education, 41(3), 39-54. https://doi.org/10.14221/ajte.2016v41n3.3

Gillies, R. M. (2003). Structuring Group Interaction to Promote Thinking and Learning During Small Group Learning in High School Settings. In R. M. Gillies, \& A. F. Ashman (Eds), Co-operative learning: The Social and intelectual learning outcomes of learning groups. London: RoutledgeFalmer

Huang, F., \& Wang, Y. (2013). Analysis of Learning Motivation in Foreign Language Acquisiton: How do non-English majors Motivation Impacts Learning Outcome. Proceedings of the 2013 International Conference on the Modern Development of Humanities and Social Science. https://doi.org/10.2991/mdhss-13.2013.41

Huillet, D., Adler, J., \& Berger, M. (2011). Teachers as researchers: Placing mathematics at the core. Education as Change, 15(1), 17-32. https://doi.org/10.1080/16823206.2011.580769 
Hunsaker, S L. (2005). Output of creativity training program. Gifted quarterly, 49(4). https://doi.org/10.1177/001698620504900403

Hwang, W.-Y., Chen, N. S., Dung, J. J., \& Yang, Y. L. (2007). Multiple representation skills and creativity effects on mathematical problem solving using a multimedia whiteboard system. Educational Technology \& Society, 10, 191-212.

Johnson, D. W., \& Johnson, R. T. (1998). Learning Together and Alone: Cooperative, Competitive, and Individualistic Learning (5th ed.). Allyn \& Bacon, Boston, MA

Kao, C. (2014). Exploring the relationships between analogical, analytical, and creative thinking. Thinking Skills and Creativity, 13, 80-88. https://doi.org/10.1016/j.tsc.2014.03.006

Kember, D., \& Leung, D. Y. P. (2005). The influence of active learning experiences on the development of graduate capabilities. Studies in Higher Education, 30(2), 155-170. https://doi.org/10.1080/03075070500043127

Konstantinou-Katzi, P., Tsolaki, E., Meletiou-Mavrotheris, M., \& Koutselini, M. (2013). Differentiation of teaching and learning mathematics: an action research study in tertiary education. International Journal of Mathematical Education in Science and Technology, 44(3), 332-349. https://doi.org/10.1080/0020739X.2012.714491

Korn, J. H. (2010). Thinking About Mathematical Thinking. PsycEXTRA Dataset. https://doi.org/10.1037/e669122011-001

Krulik, S., \& Rudnick, J. A. (1999). Innovative tasks to improve critical and creative thinking skills. In L. V. Stiff, \& F. R. Curcio (Eds.), Developing mathematical reasoning in grades K-12 (pp. 138-145). Reston, VA: National Council of Teachers of Mathematics.

Lau, S., Liem, A. D., \& Nie, Y. (2008). Task- and self-related pathways to deep learning: The mediating role of achievement goals, classroom attentiveness, and group participation. British Journal of Educational Psychology, 78(4), 639-662. https://doi.org/10.1348/000709907X270261

Lin, C., Kuo, T., Kuo, Y., Kuo, Y., Ho, L., \& Lin, C. (2007). Practice makes better? A study of meditation learners in a classroom environment. Educational Studies, 33(1), 65-80. https://doi.org/10.1080/03055690600948216

Lin, W.-L., Shih, Y.-L., Wang, S.-W., \& Tang, Y.-W. (2018). Improving junior high students' thinking and creative abilities with an executive function training program. Thinking Skills and Creativity, 29, 87-96. https://doi.org/10.1016/j.tsc.2018.06.007

Lithner, J. (2011). University Mathematics Students' Learning Difficulties. Education Inquiry, 2(2), 289-303. https://doi.org/10.3402/edui.v2i2.21981

Liu, Z. K., He, J., \& Li, B. (2015). Critical and creative thinking as learning processes at top-ranking Chinese middle schools: possibilities and required improvements. High Ability Studies, 26(1), 139-152. https://doi.org/10.1080/13598139.2015.1015501

Lockette, K. F. (2012). Creativity and Chinese education reform. International Journal of Global Education, 1, 34-39.

Montag-Smit, T., \& Maertz, C. P. (2017). Searching outside the box in creative problem solving: The role of creative thinking skills and domain knowledge. Journal of Business Research, 81, 1-10. https://doi.org/10.1016/j.jbusres.2017.07.021

Moreno, G. A., \& Rutledge, D. (2017). A response to strategies and tactics through participatory action research in a developmental mathematics course. Educational Action Research, 26(3), 420-438. https://doi.org/10.1080/09650792.2017.1351384

Mostofo, J., \& Zambo, R. (2015). Improving instruction in the mathematics methods classroom through action research. Educational Action Research, 23(4), 497-513. https://doi.org/10.1080/09650792.2015.1019903

Neber, H., He, J., Liu, B.-X., \& Schofield, N. (2008). Chinese High-School Students in Physics Classroom as Active, Self-Regulated Learners: Cognitive, Motivational and Environmental Aspects. International Journal of Science and Mathematics Education, 6(4), 769-788. https://doi.org/10.1007/s10763-007-9110-y

Newton, L., \& Newton, D. (2010). Creative Thinking and Teaching for Creativity in Elementary School Science. Gifted and Talented International, 25(2), 111-124. https://doi.org/10.1080/15332276.2010.11673575

Økland, G. M. (2012). Determinants of Learning Outcome for Students at High School in Norway: A 
Constructivist Approach. Scandinavian Journal of Educational Research, 56(2), 119-138. https://doi.org/10.1080/00313831.2011.568622

Padget, S. (2013). Creativity and critical thinking. New York: Routledge

Phan, H. P. (2005). Examination of student learning approaches, reflective thinking, and epistemological beliefs. Electronic Journal of Research in Educational Psychology, 10, 577-610

Pintrich, P. R., \& Schunk, D. H. (2001). Motivation in education: theory, research, and applications. Upper Saddle River, NJ, Prentice-Hall.

Pringle, A., \& Sowden, P. T. (2017). The Mode Shifting Index (MSI): A new measure of the creative thinking skill of shifting between associative and analytic thinking. Thinking Skills and Creativity, 23, 17-28. https://doi.org/10.1016/j.tsc.2016.10.010

Rahman, R. A., Yusof, Y. M., \& Baharun, S. (2012). Improving the Teaching of Engineering Mathematics using Action Research. Procedia - Social and Behavioral Sciences, 56, 483-493. https://doi.org/10.1016/j.sbspro.2012.09.680

Roselainy et al. (2010). Factors Affecting Students' Change of Learning Behaviour. Proceedings of The 3rd RegionalConference on Engineering Education \& Research in Higher Education (RCEE and RHEd 2010), 7-9 June, Sarawak, Malaysia

Slavin, R. E. (1995). Cooperative Learning: Theory, Research and Practice (2nd ed.). Boston, MA: Allyn \& Bacon.

Slavin, R. E. (2009). Cooperative learning. In G. McCulloch, \& D. Crook (Eds.), International Encyclopedia of Education. Routledge, Abington, UK

Slavin, R. E. (2015). Cooperative learning. Johns Hopkins University, Baltimore, MD, USA; and University of York, York, England: Elsevier Ltd.

Slavin, R. E., Lake, C., \& Groff, C. (2009). Effective Programs in Middle and High School Mathematics: A Best-Evidence Synthesis. Review of Educational Research, 79(2), 839-911. https://doi.org/10.3102/0034654308330968

Speer, N. M., Smith, J. P., \& Horvath, A. (2010). Collegiate mathematics teaching: An unexamined practice. The Journal of Mathematical Behavior, 29(2), 99-114. https://doi.org/10.1016/j.jmathb.2010.02.001

Supu, S. F. (2018). Effectiveness Of The Implementation Of Cooperative Learning Model Of Tps-Snowball Throwing Type In Mathematics Learning Of Class VII Student At SMPN 5 MAROS. Jurnal Daya Matematis, 6(2), 214. https://doi.org/10.26858/jds.v6i2.6062

Tawarah, H. M. (2017). The Degree to Which Teachers Practicing Teaching in Shobak University College by Using Creative Thinking Skills as Perceived by Students. Journal of Social Sciences, 51(1-3), 17-22. https://doi.org/10.1080/09718923.2017.1305578

Towers, J., Martin, L. C., \& Heater, B. (2013). Teaching and learning mathematics in the collective. The Journal of Mathematical Behavior, 32(3), 424-433. https://doi.org/10.1016/j.jmathb.2013.04.005

Von Lockette, P. (2012). Actuation Behavior in Patterned Magnetorheological Elastomers: Simulation, Experiment, and Modeling. Volume 1: Development and Characterization of Multifunctional Materials; Modeling, Simulation and Control of Adaptive Systems; Structural Health Monitoring. https://doi.org/10.1115/SMASIS2012-8143

Wang, T.-Y., \& Hsieh, F.-J. (2017). Taiwanese high school students' perspectives on effective mathematics teaching behaviors. Studies in Educational Evaluation, 55, 35-45. https://doi.org/10.1016/j.stueduc.2017.06.001

Webb, N. M. (2008). Learning in small groups. In T. L. Good (Ed.), 21st Century Education: A Reference Handbook (pp. 203-211). Sage, Los Angeles, CA. https://doi.org/10.4135/9781412964012.n22

Wechsler, S. M., Saiz, C., Rivas, S. F., Vendramini, C. M. M., Almeida, L. S., Mundim, M. C., \& Franco, A. (2018). Creative and critical thinking: Independent or overlapping components? Thinking Skills and Creativity, 27, 114-122. https://doi.org/10.1016/j.tsc.2017.12.003

Wolfle, J. A. (1986). Enriching the mathematics program for middle school gifted students. Roeper Review, 9 , 81-85. https://doi.org/10.1080/02783198609553015

Yi, Z., \& LuXi, Z. (2012). Implementing a cooperative learning model in universities. Educational Studies, 38(2), 
165-173. https://doi.org/10.1080/03055698.2011.598687

Zhao, X.-J., \& Zhao, X.-T. (2012). Another way to develop Chinese students' creativity: Extracurricular innovation activities. US-China Education Review, B, 6, 566-571.

Ziegler, A. (2009). Research on giftedness in the 21 st century. In L. V. Shavinina (Ed.), International handbook on giftedness (pp. 1509-1524). Amsterdam: Springer. https://doi.org/10.1007/978-1-4020-6162-2_78

Zohar, A., \& Dori, J. (2003). Higher order thinking skills and low-achieving students: Are they mutually exclusive?. The Journal of the Learning Sciences, 12, 1445-1445. https://doi.org/10.1207/S15327809JLS1202_1

Zohar, A., Degani, A., \& Vaaknin, E. (2001). Teachers' beliefs about low-achieving students and higher order thinking. Teaching and Teacher Education, 17(4), 469-485. https://doi.org/10.1016/S0742-051X(01)00007-5

\section{Copyrights}

Copyright for this article is retained by the author(s), with first publication rights granted to the journal.

This is an open-access article distributed under the terms and conditions of the Creative Commons Attribution license (http://creativecommons.org/licenses/by/4.0/). 